Buletin JSJ, 1 (1), 2019, 1-13

Available online di: http://ejournal-balitbang.kkp.go.id/index.php/JSJ/index

\title{
PENETAPAN DAN PENGENDALIAN TITIK KENDALI KRITIS HISTAMIN PADA \\ PENGOLAHAN TUNA STEAK BEKU (Thunnus sp.) DI PT. PERMATA MARINDO JAYA MUARA BARU - JAKARTA UTARA
}

\section{DETERMINING AND MONITORING CRITICAL CONTROL POINT (CCP) HISTAMIN AT FROZEN TUNA STEAK PROCESSING (Thunnus sp.) IN PT. PERMATA MARINDO JAYA, MUARA BARU - JAKARTA UTARA}

\author{
Gadis Mila Rosa Perdana ${ }^{1}$, Widodo Sumiyanto ${ }^{2}$ dan Yuliati H. Sipahutar ${ }^{1}$ \\ 1 Jurusan Pengolahan Hasil Perikanan, Sekolah Tinggi Perikanan \\ JI. AUP No. 1 Pasar Minggu, Jakarta Selatan, DKI Jakarta 12520 \\ 2) Badan Karantina Ikan, Pengendalian Mutu dan Keamanan Hasil Perikanan, \\ Email: gadismila@gmail.com
}

\begin{abstract}
ABSTRAK
Penelitian ini bertujuan untuk mengamati praktik berproduksi yang baik tuna steak beku, Prosedur Operasi Standar Sanitasi, menganalisis penetapan dan mengendalikan bahaya histamin pada titik kendali kritis. Metode dilakukan dengan survey dan observasi. Hasil penelitian menunjukkan cara berproduksi yang baik sudah baik namun pada penerimaan bahan baku yaitu audit approval supplier kurang dilakukan dengan ketat dibuktikan dengan kurang diterapkannya sanitasi, penanganan yang baik dan higienis saat pembongkaran ikan. Penerapan 8 kunci sanitasi sesuai prosedur perusahaan namun pencegahan kontaminasi silang belum diterapkan yaitu masih ditemukan klip hitam besi di ruang UV 1 yang dapat mencemari produk dengan serpihan logam. Namun pengendali mutu segera melakukan pembenahan setelah ditemukannya klip kertas hitam besi di ruang UV 1 sehingga tidak ditemukan klip kertas hitam besi atau benda-benda yang dapat mencemari produk lagi pada ruang proses. Penerapan 12 langkah HACCP sesuai prosedur, namun verifikasi pada audit internal terhadap penerapan kunci SSOP pencegahan kontaminasi silang kurang dilakukan. Pengendalian titik kritis histamin sudah dilaksanakan dengan baik dibuktikan dengan kadar histamin tidak ada yang melebihi standar perusahaan yaitu $17 \mathrm{mg} / \mathrm{l}$.
\end{abstract}

Kata Kunci : CCP , GMP , HACCP., Histamin , SSOP, Tuna Steak Beku.

\begin{abstract}
This study aims to observe the Good Manufacturing Practices (GMP) of Frozen Steak Tuna, Sanitation Standard Operating Procedures (SSOP), analyze the determination and control of the hazards of histamine on Critical Control Points (CCP). The method is done by survey and observation. The results showed that GMP was good but the acceptance of raw materials namely supplier audit approval was not carried out rigorously evidenced by sanitation, hygiene and Good Handling Practices (GHP) were not applied when unloading fish. Application of 8 SSOP keys according to company procedures, but prevention of cross contamination was not applied, namely a black iron clip was found in the UV 1 chamber that could contaminate the product with metal debris. However, Quality Control immediately made improvements after the discovery of black iron paper clips in UV 1 space so that no black iron paper clips or objects that could contaminate the product in the processing room were found. Implementation of the HACCP 12 steps is according to procedure, but verification on internal audits of the application of the key SSOP to prevent cross contamination is not done. The control of the critical control point (CCP.) Histamine levels has been carried out well, none of which exceed the company's standards of $17 \mathrm{mg} / \mathrm{l}$.
\end{abstract}

Keywords: CCP, GMP, HACCP, Histamine, SSOP, Frozen Steak Tuna 


\section{PENDAHULUAN}

Penanganan ikan hasil tangkapan di kapal merupakan perlakuan terpenting dari seluruh proses perjalanan ikan hingga sampai ke konsumen. Tempat Pelelangan Ikan (TPI), dimana ikan-ikan hasil tangkapan nelayan dibongkar dari kapal, didaratkan untuk selanjutnya didistribusikan, tentunya harus dilakukan penanganan agar mutunya tidak menurun. Menurut Junianto (2003), penurunan mutu ikan dapat dihambat dengan perlakuan suhu rendah. Penggunaan suhu rendah berupa pendingin dan pembeku dapat memperlambat prosesproses biokimia yang berlangsung dalam tubuh ikan yang mengarah pada penurunan mutu ikan.

Histamin merupakan senyawa amin biogenik yang dihasilkan dari proses dekarboksilasi histidin bebas ( $\alpha$-amina- $\beta$-inidosal asam propionat). Proses pembentukkan histamin pada ikan sangat dipengaruhi oleh aktivitas enzim L-Histidine (Hdc) (Mangunwardoyo dalam Nurjanah et al., 2011). Ketika batas kritis sensori belum terpenuhi, saat ini direkomendasikan dilakukan analisis histamin minimal 60 ikan, dikumpulkan secara representatif dari seluruh lot dan dilakukan reject jika ada ikan yang ditemukan dengan tingkat histamin lebih besar dari atau sama dengan 50 ppm (FDA, 2011). Food and Drugs Administrations (FDA) juga menentukan batas kritis suhu untuk suhu ikan yaitu $4,4^{\circ} \mathrm{C}$.

Peran pemerintah dalam menjamin keamanan pangan mengeluarkan kebijakan yang berupa PERMENKP Per.01/Men/2007 tentang pengendalian sistem jaminan mutu dan keamanan pangan serta HACCP merupakan salah satu syarat suatu perusahaan untuk dapat melakukan ekspor keluar negeri yaitu Asia, Amerika dan Eropa.

Pengendalian titik kritis adalah pendekatan sistematis untuk mengidentifikasi, mengevaluasi, dan mengendalikan bahaya keamanan pangan. Titik kendali kritis dapat diketahui dengan menggunakan decision tree atau pohon keputusan serta dapat dikendalikan dengan menggunakan tabel pengendalian titik kendali kritis.

Penelitian ini bertujuan untuk mengetahui cara berproduksi yang baik tuna steak beku, 8 kunci sanitasi tuna steak beku, dan menganalisis pengendalian histamin pada titik kendali kritis

\section{METODE PENELITIAN}

Penelitian ini dilakukan tanggal 4 Maret sampai dengan tanggal 2 Juni 2019, yang bertempat di unit pengolahan tuna steak mentah beku di PT. Permata Marindo Jaya dan Pusat Produksi Inspeksi Sertifikasi Hasil Perikanan (PPISHP) Jakarta Utara.

Alat yang digunakan adalah bak penampung, keranjang, meja stainless steel, pisau, thermometer, timbangan analitik, score sheet SKP. Bahan yang digunakan adalah ikan tuna utuh beku, produk tuna steak mentah beku, air dan es. Asam phospat, Resin penukar ion jenis dowex, pembuatan larutan standar histamin.

\section{Pengamatan Cara Berproduksi yang Baik Tuna Steak Beku}

Penelitian dilakukan pada alur proses sejak bahan baku diterima hingga distribusi. Pengamatan alur proses pengolahan tuna steak beku dilakukan dengan cara ikut serta dalam proses pengolahan tuna steak beku dibandingkan dengan acuan SNI 01-4485.3-2006.

\section{Pengujian kimia (histamin)}

Pengujian histamin menggunakan metode spektrofluorometri, Bahan baku diambil satu sampel secara acak sebanyak 7 kali pengujian dengan 3 kali pengulangan dengan kapal yang berbeda setiap kali pengujian saat bahan baku, penyuntikkan $\mathrm{CO}$ dan pembentukkan steak dengan interval satu minggu. Untuk sampel tuna steak beku dithawing sebelum dilakukan pengujian. Pengujian histamin dilakukan sesuai dengan SNI 2345.10.2016. 
Buletin JSJ, 1 (1), 2019, 1-13

Available online di: http://ejournal-balitbang.kkp.go.id/index.php/JSJ/index

\section{Pengamatan Sanitasi}

Penngujian sanitasi mengacu pada 8 kunci sanitasi yaitu keamanan air dan es; kondisi dan kebersihan permukaan yang kontak dengan bahan pangan; pencegahan kontaminasi silang; menjaga fasilitas pencuci tangan, sanitasi dan toilet; proteksi dari bahan-bahan kontaminasi; pelabelan, penyimpanan dan penggunaan bahan toksin; pengawasan kondisi kesehatan personil; serta pengendalian pest.

\section{Pengendalian Potensi Bahaya Histamin sebagai Titik Kendali Kritis}

Sebelumnya dilakukan penilaian sanitasi, penanganan yang baik dan higienis pada pembongkaran ikan (kapal dan transit), dengan menggunakan daftar penilaian unit pengolahan ikan yang diterbitkan oleh Direktorat Jenderal Pengolahan dan Pemasaran Hasil Perikanan tahun 2007 (KEP 011.P2HP. 2007). Penilaian resiko bahaya histamin terdiri dari identifikasi bahaya, karakteristik bahaya, penilaian paparan bahaya dan karakteristik bahaya (FAO, 2004) dan mengamati program approval supplier perusahaan. Untuk identifikasi titik kendali kritis dilakukan dengan pohon keputusan.

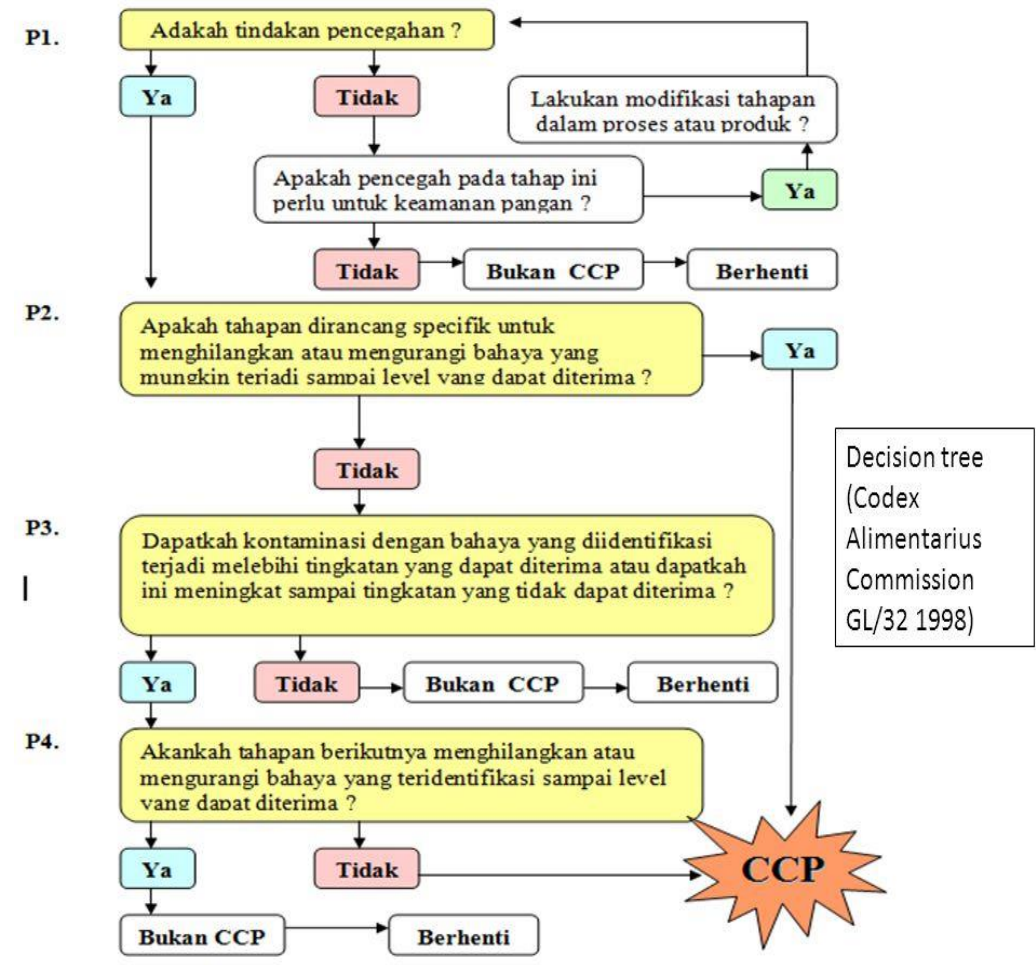

Gambar 1. Skema penilaian resiko bahaya histamin

\section{Metode Analisis Data}

Analisis dilakukan dengan komparatif yaitu analisis yang membandingkan hasil pengamatan secara kuantitatif yang selanjutnya dikaitkan dengan literatur ataupun dengan pengamatan lain yang serupa, apakah terdapat kesamaan atau perbedaan hasil pengamatan dengan bahan perbandingan tersebut. Hasil uji kadar histamin kemudian dibandingkan dengan FDA guidance dan SNI 4485.1-2006 mengenai batas maksimum histamin dalam tuna steak beku. 
HASIL DAN PEMBAHASAN

\section{Pengamatan Cara Berproduksi yang Baik Tuna Steak Beku}

\section{Penerimaan bahan baku}

Ikan Tuna yang diterima jenis yellow fin dan big eye dari approval dan daerah penangkapannya adalah WPP 57. Bahan baku tuna segar dibongkar dari kapal dan dipindah ke transit terlebih dahulu untuk dilakukan sortasi grade A, B, C, D dan penimbangan berat ikan. Perbedaan grade ini didasarkan warna daging ikan, bentuk tubuh, kekerasan tekstur, kecerahan serta kandungan lemak daging tuna. Namun sanitasi, penanganan yang baik dan higienis kurang diterapkan saat pembongkaran ikan di transit.

\section{Pencucian 1}

Ikan ikan tuna dicuci dengan cara disikat dan disiram air kran dengan air ozon secara merata. Air yang digunakan untuk proses pencucian adalah air yang bersumber dari PDAM. Air tersebut digunakan untuk proses produksi, mencuci peralatan, mencuci tuna dan proses pembuatan es curai. Hal ini sesuai dengan Rosal \& Agüera (2008) bahwa air yang mengalami treatmen ozon akan mengurangi jumlah bakteri patogen yang dikandung air.

\section{Penyimpanan Sementara}

Bahan baku yang telah melewati proses pencucian kemudian dimasukkan ke dalam bak penampungan ikan sementara untuk menunggu menunngu hasil uji histamin. Jika hasil uji $<17$ ppm maka ikan akan mengalami proses selanjutnya. Bahan baku ikan segar yang dimasukkan ke bak penyimpanan sementara ditimbun dengan flakes ices untuk menjaga suhu ikan $<4,4^{\circ} \mathrm{C}$ dan bahan baku ikan beku dimasukkan ke cold storage bahan baku untuk menjaga suhu <$18^{\circ} \mathrm{C}$ (suhu pusat ikan beku).

\section{Pemotongan Kepala}

Proses pemotongan kepala tergantung jenis bahan baku. Jika bahan baku berbentuk beku (frozen) maka dilakukan dengan mesin sedangkan jika bahan baku berbentuk segar (fresh) dilakukan dengan manual dengan menggunakan pisau. Kepala harus dipindahkan secepat mungkin dari meja dan dibuang ke bak penampungan limbah untuk mencegah terjadinya kontaminasi bakteri. QC mengecek suhu ikan secara acak (random).

\section{Pencucian II}

Pencucian dilakukan dengan cara mengalirkan air dingin ke seluruh permukaan produk sambil digosok menggunakan tangan supaya kotoran dan sisa daging yang menempel pada produk dapat terlepas. Air yang digunakan untuk proses pencucian adalah air yang bersumber dari PDAM yang telah memenuhi persyaratan air minum serta melewati treatment penyinaran dengan sinar ultraviolet dan ozonisasi untuk membunuh bakteri patogen pada air. Hal ini sesuai dengan Rosal \& Agüera (2008) bahwa air yang mengalami treatment ozon akan mengurangi jumlah bakteri patogen yang dikandung air..

\section{Pemotongan Loin}

Proses pemotongan loin tergantung dari jenis bahan baku. jika bahan baku berbentuk segar (fresh) maka pemotongan loin dilakukan secara manual menggunakan pisau bersih yang sebelumnya telah diasah. Jika bahan baku dalam bentuk berbentuk beku (frozen) maka dilakukan dengan mesin pemotong otomatis (band saw bandsaw). Pemotongan loin dimulai dari dengan membelah daging ikan menjadi dua bagian sepanjang bagian gurat sisi (Linear lateralis), lalu dilakukan pemotongan dari bagian perut sampai pangkal ekor dan dari bagian punggung sampai pangkal ekor dan dari panggilan punggung sampai pangkal ekor, sehingga didapatkan dua bagian daging yang terlepas dari tulang. Sisi lainnya dilakukan proses yang sama, sehingga dari satu ikan akan diperoleh empat bagian loin 
Buletin JSJ, 1 (1), 2019, 1-13

Available online di: http://ejournal-balitbang.kkp.go.id/index.php/JSJ/index

\section{Perapihan dan Pengulitan}

Tahapan perapihan dan pengulitan bahan baku segar (fresh) secara manual menggunakan pisau yang sebelumnya sudah diasah. Pada bahan baku beku (frozen) pengulitan dan perapihan dilakukan dengan pembuangan daging berwarna gelap menggunakan pisau potong kemudian menggunakan pisau yang berbentuk lengkung untuk memudahkan dalam pembuangan daging gelap yang menjorok ke dalam sekaligus membuang sisa-sisa tulang dan isi perut. Setelah itu, tahap pembuangan kulit dilakukan dari kulit bagian ekor sampai ke bagian badan ikan. Daging tuna yang berwarna gelap dibuang karena dapat menimbulkan ketengikan. Hal ini sesuai dengan pendapat Sahril \& Lekahena (2015) Warna merah pada daging ikan disebabkan kandungan hemoprotein tinggi yang tersusun atas protein miosin, globin dan struktur heme yang dikenal dengan nama mioglobin dan hemoglobin, merupakan senyawa bersifat peroksidan.

\section{Pelelehan (Thawing) Loin Beku}

Loin yang berasal dari bahan baku ikan beku dilelehkan terlebih dahulu sebelum dilakukan penyuntikkan gas carbon monoxide (CO) hal ini bertujuan mempermudah dan mempersingkat proses penyuntikan gas $\mathrm{CO}$ ke daging ikan. Loin dimasukkan ke plastik yang berisi gas $\mathrm{CO}$ saat di thawing hal ini dimaksudkan untuk menciptakan suasana anaerob sehingga bakteri aerob tidak dapat tumbuh. Suhu loin selalu dipantau $<3,3^{\circ} \mathrm{C}$ agar bakteri anaerob tidak dapat tumbuh menurut FDA (2011) Clostridium botulinum tipe $\mathrm{E}$ dan non proteolitik $\mathrm{B}$ dan $\mathrm{F}$ dapat tumbuh pada suhu $3,3-5^{\circ} \mathrm{C}$ pada kondisi anaerob dalam jangka waktu 7 hari. Pelelehan (Thawing) dilakukan di dalam ruangan dalam jangka waktu 18-24 jam.

\section{Penyuntikan gas Carbon Monoxide (CO)}

Bahan beku yang telah dilakukan pelelehan dikeluarkan dari plastik dan dapat dilakukan penyuntikkan $\mathrm{CO}$. Penyuntikan gas $\mathrm{CO}$ ini dilakukan secara otomatis dengan mesin. Loin diletakkan pada conveyor yang akan berjalan menuju mesin suntik. Penambahan gas $\mathrm{CO}$ berfungsi untuk menstabilkan warna daging. Menurut Europian Commission (2001) Campuran gas $\mathrm{CO}_{2}$ dan $\mathrm{CO}$ menghambat pertumbuhan L. monocytogenes, $Y$. Enterocolitica dan $E$. coli O157: H7 sedangkan menurut FDA (2007) pada rapatnya mengenai Substances Generally Recognized As Safe (GRAS) menyatakan bahwa CO aman digunakan dengan memberi label pada kemasan produk "CO treated".

\section{Pendinginan Sementara}

Pendinginan sementara dilakukan pada ruangan chilling denga suhu ruangan $0-3,3^{\circ} \mathrm{C}$. Pendinginan ini dilakukan selama 1-2 hari. Hal ini sependapat dengan Djenane (2018) Pada suhu $10^{\circ} \mathrm{C}$ ampuran gas $\mathrm{CO}_{2}$ dan $\mathrm{CO}$ menghambat pertumbuhan L. monocytogenes, $Y$. enterocolitica dan E. colli O157: $\mathrm{H} 7$ namun tidak dapat mencegah pertumbuhan bakteri Salmonella maka diperlukan pendinginan sementara untuk menurunkan suhunya menjadi $3,3^{\circ} \mathrm{C}$. Menurut FDA (2011) Salmonella dapat tumbuh dengan suhu minimal $5,2^{\circ} \mathrm{C}$.

Produk Loin dibungkus dengan plastik tanpa oksigen yang memiliki kode setiap plastiknya. Penyimpanan dilakukan dengan cara disusun di rak-rak dan menerapkan sistem First In First Out (FIFO) yaitu barang yang masuk ke chilling room lebih dulu akan dikeluarkan pertama. $\mathrm{Hal}$ ini sesuai dengan Keputusan Menteri Ketenagakerjaan nomor 78 tahun 2016 bahwa produk dalam keranjang/rak disusun dalam chilling room dan menerapkan sistem First In First Out (FIFO).

\section{Penyinaran Ultraviolet (UV) 1}

Setelah dilakukan penyimpanan sementara selanjutnya disinari UV untuk meminimalkan jumlah bakteri pada permukaan loin. Hal ini sesuai dengan pendapat Koutchma (2014) penyinaran UV ke daging, permukaan dapat menurunkan jumlah mikroba yang terdapat pada permukaannya. Jenis sinar yang digunakan adalah sinar ultraviolet $\mathrm{C}$, yaitu sinar yang memilki 
panjang gelombang pendek sekitar 280-10 nm. Loin dilewatkan sinar UV melalui conveyor berjalan, hal ini sesuai dengan Stermer et. al. (1987) dan Koutchma (2014) Sinar ultraviolet (UV) sepeti radiasi gama yaang memiliki panjang gelombang 220-300 nm dapat membunuh bakteri dengan cara menghancurkan dinding sel bakteri tersebut dan penurunan jumlah baktri tersebut adalah $10^{2}$ sampai $10^{3}$. Menurut Vermeulen et. al. (2008) strain bakteri E. colli ATCC 25922 dapat mati pada penyinaran ultraviolet pada panjang gelombang 250-232 nm.

\section{Pembentukan Steak}

Pemotongan steak dilakukan secara manual menggunakan pisau yang bersih. Pisau diasah dan dicuci dengan air yang berklorin $100 \mathrm{ppm}$ dan disemprot alkohol 70\%. Pada tahap ini dilkukan dengan bersih, dingin, cepat, hati-hati dan dilakukan oleh operator yang terlatih. Produk juga dipisahkan berdasarkan warna yake (pelanginya). Produk A3 adalah produk dengan warna merah cherry (yake tipis), produk A2 adalah produk yang memiliki warna cokelat terang (yake agak tebal) dan produk A3 adalah produk yang dijual lokal karena memiliki daging cokelat tua.

\section{Pengemasan Vakum}

Tuna steak divakum dengan tekanan 1 atm. Jika ada produk yang belum dalam keadaan vakum maka akan diganti kemasannya dan akan dilakukan pemvakuman ulang. Produk steak tuna yang telah divakum kemudian dilakukan penimbangan kembali untuk mengetahui berat produk steak yang telah dihasilkan. Penimbangan dilakukan menggunakan timbangan yang sebelumnya telah dikalibrasi internal oleh QC.

Oksidasi terjadi karena kandungan lemak yang terdapat pada daging tuna. Bentuk kerusakan lemak yang terutama adalah ketengikan. Ketengikan pada umumnya ditandai dengan adanya penurunan mutu berupa rasa dan bau yang terdapat pada bahan yang berlemak. Lemak mudah mengalami ketengikan oleh karena proses oksidasi yang sering dinamakan otooksidasi. Selama masa reaksi oto-oksidasi akan terbentuk senyawa peroksida. Reaksinya dipercepat karena adanya cahaya, kenaikan suhu, adanya oksigen, dan kelembapan (Suwetja, 2011).

\section{Penyinaran Ultraviolet (UV) II}

Tuna steak setelah dilakukan pemvakuman maka dilakukan penyinaran ultraviolet kembali. $\mathrm{Hal}$ ini bertujuan untuk mengurangi bakteri yang ada di permukaan produk akibat kontaminasi dari pekerja dan kemasan. Hal ini sesuai dengan pendapat Koutchma (2014) penyinaran UV ke daging dan permukaan telur dapat menurunkan jumlah mikroba yang terdapat pada permukaannya.

Produk akan disinari dengan sinar ultraviolet ke seluruh bagian produk saat melewati mesin UV. Jenis sinar yang digunakan adalah sinar ultraviolet $C$, yaitu sinar yang memilki panjang gelombang pendek sekitar 280-10 nm. Produk dimasukan satu per satu oleh karyawan secara rapi dan tidak bertumpukan. Setiap sebelum produksi, setiap satu jam sekali selama produksi dan setelah proses produksi, operator memeriksa keadaan lampu dengan menggunakan alat khusus. Operator memeriksa dan memastikan lampu dalam keadaan tidak rusak.

\section{Pembekuan}

Tuna steak yang telah dilewatkan sinar UV dimasukkan ke mesin pembeku Air Blast Freezer (ABF). Pembekuan menggunakan ABF dilakukan selama 8 jam dengan suhu minimum $-25^{\circ} \mathrm{C}$ dengan suhu pusat ikan menjadi $-18^{\circ} \mathrm{C}$. Menurut FDA (2011) Pada kemasan yang direduksi oksigennya, Clostridium botulinum non-proteolitik tidak dapat mati kecuali dengan mengatur suhu di bawah $3,3^{\circ} \mathrm{C}$. Waktu tumbuh bakteri ini adalah 7 hari. Fluktuasi suhu dapat dilihat pada data logger yang dipantau QC. Alat ini sangat fleksibel, dapat digunakan untuk membekukan ikan dengan bentuk dan ukuran yang berlainan secara serentak (Afrianto \& Liviawaty,1989). 
Buletin JSJ, 1 (1), 2019, 1-13

Available online di: http://ejournal-balitbang.kkp.go.id/index.php/JSJ/index

\section{Pendeteksian Logam}

Terdapat dua jenis metal detector (pendeteksi logam) pada PT Permata Marindo Jaya. Masing-masing memiliki sensitivitas tertentu. Metal Detector yang pertama memiliki sensitivitas Fe maksimal $\phi 2,5 \mathrm{~mm}$, non Fe $\phi 3,0 \mathrm{~mm}$ dan SUS 304 adalah $\phi 2,5 \mathrm{~mm}$. Sensitivitas kalibrasi dari alat Metal Detector kedua untuk Fe maksimal $\phi 1,75 \mathrm{~mm}$, non Fe $\phi$ $2,5 \mathrm{~mm}$ dan SUS 304 adalah $\phi 4,00 \mathrm{~mm}$. Tuna Steak yang telah dikemas kedalam polybag kemudian dilewatkan satu persatu pada alat metal detector. Sebelum digunakan metal detector di cek sensitivitasnya dan di setting untuk jenis produk yang akan dilewatkan.

\section{Penyinaran Ultravilolet (UV) III}

Jenis sinar yang digunakan adalah sinar ultraviolet $\mathrm{C}$, yaitu sinar yang memilki panjang gelombang pendek sekitar 280-10 $\mathrm{nm}$. Operator memeriksa dan memastikan lampu dalam keadaan utuh serta tidak retak atau pecah. Hasil pemeriksaan dicatat di dalam lembar kerja yang telah tersedia. Jika ditemukan serpihan kaca pada produk atau ditemukan lampu ultraviolet yang pecah, maka hold produk yang telah melewati mesin ultraviolet 1 jam sebelum ditemukan serpihan kaca dan akan dilakukan perbaikan mesin ultraviolet.

\section{Pengepakan dan Pelabelan}

Proses pengepakan dilakukan dengan menyusun produk dalam master carton yang di dalamnya juga terdapat bubble pack di antara produk tuna steak yang ada. Fungsi bubble pack yaitu untuk melindungi produk dari benturan dan kerusakan selama transportasi maupun penyimpanan. Produk yang dikemas diberi label sesuai kode produksi yang ditetapkan. Dalam proses pengemasan didalam master carton ini hal yang perlu dilakukan sebagai bentuk pengawasan adalah sistem penulisan atau pengkodean yang menyangkut antara kesesuaian isi dengan keterangan yang ada pada Master Carton tersebut. Penulisan label dalam Master Carton diantaranya nama produk, nama merek dagang, size produk, jenis produk vakum, komposisi, pernyataan allergen, kode produksi, berat bersih, tanggal kedaluarsa dan tanggal produksi, produksi negara dan cara penyajian.

\section{Penyimpanan Beku}

Produk disimpan pada ruang penyimpanan beku (cold storage) dengan suhu $-20^{\circ} \mathrm{C}$. Produk yang telah dikemas dengan rapi selanjutnya diangkut ke Cold storage. Produk disimpan berdasarkan Penyimpanan produk dalam Cold storage diklasifikasikan sesuai dengan jenis produk dan brand sehingga mudah untuk mencari. Hal ini bertujuan untuk memudahkan mengidentifikasi keluar masuknya produk dalam gudang beku. Hal ini sesuai dengan BSN (2006) Penyimpanan tuna steak beku harus dalam gudang beku (cold storage) dengan suhu maksimum $-20^{\circ} \mathrm{C}$. Penataan produk dalam gudang beku diatur sedemikian rupa sehingga memungkinkan sirkulasi udara dapat merata dan memudahkan pembongkaran. Produk yang diatur pada dinding ruang pendingin dan diberikan jarak sehingga ada sirkulasi udara yang baik. Produk disusun sesuai urutan produk masuk sehingga memudahkan dalam sistem First In First Out (FIFO)

\section{Pemuatan}

Proses pemuatan dilakukan dengan cara memindahkan produk dari dalam cold storage ke dalam container melalui loket pengiriman produk. Saat pemindahan produk, blower yang berada di sepanjang anteroom dinyalakan untuk membuat suhu ruangan tetap rendah $<12^{\circ} \mathrm{C}$ untuk mencegah kenaikan suhu produk. Pemindahan produk dilakukan secara manual oleh karyawan secara cepat, bersih dan hati-hati. Master karton disusun secara rapi agar sistem pendinginan produk dapat merata.

Saat container sudah terisi penuh, petugas QC menempelkan data logger di bagian dalam container untuk mencatat dan merekam suhu container selama pendistribusian berlangsung. Setelah segel pada data logger dicabut, secara otomatis data logger akan merekam suhu pada 
container. Selama distribusi produk beku, suhu pusat produk harus dipertahankan senantiasa maksimum $-18^{\circ} \mathrm{C}$.

\section{Pengujian Kimia}

Pengujian histamin dilakukan dengan Veratox dan diverifikasi dengan metode spektroflorometri, dengan mengambil 7 sampel dari 7 kapal approval supplier. Pengambilan sampel dilakukan pada bagian ekor, perut dan bawah sirip ikan tuna. Pengambilan sampel dilakukan dengan cara mengkompositan 3 ikan menjadi satu sampel.

Tabel 1. Kadar Histamin Bahan Baku, Setelah CO dan Pembentukkan Steak dengan Veratox

\begin{tabular}{l|c|c|c|c}
\hline \multirow{2}{*}{ Nama Kapal } & \multirow{2}{*}{$\begin{array}{c}\text { Bagian yang } \\
\text { Dijadikan Sampel }\end{array}$} & \multicolumn{3}{|c}{ Kadar Histamin (ppm) } \\
\cline { 3 - 5 } & & $\begin{array}{c}\text { Penerimaan } \\
\text { Bahan Baku }\end{array}$ & $\begin{array}{c}\text { Setelah } \\
\text { CO }\end{array}$ & $\begin{array}{c}\text { Pembentukkan } \\
\text { Steak }\end{array}$ \\
\hline KM Hasil Laut 21 & Ekor & 0,5 & 1 & 1 \\
\hline KM Bintang Mas 2 & Ekor & 0,2 & 0,4 & 0,5 \\
\hline KM Bintang Barat & Perut & 0,1 & 0,2 & 0,2 \\
\hline KM Bintang Bahari 88 & Perut & 0 & 0,1 & 0,1 \\
\hline KM Cipta Jaya 89 & Perut & 0,5 & 0,6 & 0,7 \\
\hline KM Roda Terbah 9 & Sirip & 0,2 & 0,3 & 0,4 \\
\hline KM Pelita Harapan & Sirip & 0,2 & 0,3 & 0,4 \\
\hline
\end{tabular}

Kadar Histamin bahan baku pada semua sampel kapal tidak ada yang melebihi standar, yaitu $17 \mathrm{mg} / \mathrm{l}$. Kadar Histamin terkadang naik pada proses penyuntikan $\mathrm{CO}$ dan pembentukkan steak namun tidak pernah terjadi kenaikan kadar histamin yang signifikan. Kenaikan kadar histamin ini dipengaruhi oleh kenaikan suhu dan lamanya prosesing.

\section{Pengamatan Delapan Kunci Sanitasi}

\section{Keamanan air dan es}

Air yang digunakan adalah air ozon. untuk proses produksi, mencuci peralatan, mencuci ikan dan proses pembuatan es curai (flakes ices). Air yang digunakan di area produksi diperiksa setiap hari oleh laboratorium internal untuk parameter fisik dan setiap 3 bulan sekali untuk parameter biologi dan uji eksternal satu tahun sekali.

Es yang digunakan adalah flakes ices. Flakes ices dibuat sendiri. Kapasitas maksimal perhari yang dapat dihasilkan adalah 30 ton flakes ices. Untuk air yang digunakan membuat es adalah air ozon yang sudah teruji atau memenuhi syarat bersih dan terhindar dari cemaran, hal ini sesuai PERMENKES RI No. 492/MENKES/PER/IV/2010 tentang persyaratan kualitas air minum, air yang digunakan dalam industri pangan harus memenuhi persyaratan air minum. Air minum haruslah bebas dari bakteri dan senyawa-senyawa berbahaya, tidak berwarna, tidak berbau, dan tidak keruh.

\section{Kondisi Permukaan yang Kontak Langsung Dengan Produk}

Peralatan yang digunakan dirancang dan terbuat dari bahan tahan karat, mudah dibersihkan, tidak menyerap air dan tidak menyebabkan kontaminasi terhadap produk. Bahan sanitizer yang digunakan adalah klorin 17 ppm dan alkohol $70 \%$ dengan tujuan untuk menghilangkan bakteri dalam industri pengolahan produk perikanan. Pencucian peralatan dilakukan sebelum dan setelah proses berlangsung. Hal ini sesuai dengan Keputusan Menteri Kelautan dan Perikanan (2013), bahwa peralatan dan perlengkapan yang digunakan berhubungan langsung dengan ikan yang diolah harus terbuat dari bahan tahan karat, tidak menyerap air, mudah dibersihkan dan tidak menyebabkan kontaminasi terhadap hasil perikanan. 
Setiap alat memiliki tanda tertentu untuk membedakan alat ruang proses satu dengan lainnya dan untuk alat penanganan limbah dibedakan dengan alat penanganan dan pengolahan produk. Hal ini sesuai dengan Keputusan Menteri Kelautan dan Perikanan nomor 52A/KEPMEN-KP/2013 Peralatan dan perlengkapan yang digunakan harus diberi tanda dan dipisahkan dengan jelas supaya tidak dipergunakan untuk menangani ikan, bahan penolong, bahan tambahan pangan serta produk akhir.

\section{Pencegahan Kontaminasi Silang}

Beberapa prosedur yang dapat mencegah terjadinya kontaminasi terhadap produk. Monitoring yang dapat dilakukan agar prosedur dapat berjalan lancar adalah

1. Pemeriksaan seragam kerja lengkap oleh $\mathrm{QC}$ sebelum pekerja memasuki ruang proses.

2. Pemeriksaan secara visual oleh QC per bagian proses untuk memeriksa apakah ada peralatan administrasi masih ada di ruang proses.

3. Pemeriksaan secara visual oleh QC perbagian proses memastikan bahwa karyawan mencuci tangan satu jam sekali.

Tindakan koreksi yang dilakukan QC jika monitoring tidak berjalan sesuai adalah :

1. Jika ada pekerja yang tidak memakai seragam kerja lengkap maka karyawan dilarang masuk proses dan dilakukan training karyawan.

2. Jika ditemukan peralatan administrasi di ruang proses maka QC memindahkan peralatan administrasi tersebut ke luar ruang proses.

3. Apabila ada karyawan yang tidak mencuci tangan maka QC memberi peringatan untuk pekerja dan dilakukan training karyawan

4. Jika layout pabrik menyebabkan adanya kontaminasi silang maka dilakukan perubahan layout pabrik.

Prosedur yang telah ditetapkan untuk pencegahan kontaminasi silang belum dilakukan sepenuhnya oleh pekerja yaitu masih ditemukan adanya klip kertas hitam besi di ruang penyinaran UV1. Hal ini dapat mengkontaminasi produk dengan potensi bahaya serpihan logam jika kontak langsung dengan produk. Namun Quality Control segera melakukan pembenahan setelah ditemukannya klip kertas hitam besi di ruang UV 1 sehingga tidak ditemukan klip kertas hitam besi atau benda-benda yang dapat mencemari produk lagi pada ruang proses.

\section{Fasilitas Kebersihan, Toilet dan Cuci Tangan}

Fasilitas kebersihan yang terdapat di ruang proses antara lain sikat, kran sabun, serokan kecil dan serokan lantai. Fasilitas kebersihan ini diletakkan di setiap sudut ruangan proses. Fasilitas kebersihan antar ruangan diberi tanda agar tidak tertukar dengan ruangan lain dan dapat mengkontaminasi produk. Tempat pencuci tangan terletak didekat pintu masuk ruang proses pengolahan. Fasilitas pencuci tangan meliputi kran cuci tangan yang bersistem otomatis, sabun sebagai saniter, tissue dan hand dryer untuk mengeringkan tangan. juga menyediakan bak pencuci kaki yang dicampur klorin dengan konsntrasi 200 ppm di depan ruang proses.

Jumlah tempat cuci tangan adalah 5 buah dengan jumlah karyawan 67 orang. Hal ini sudah sesuai dengan PERMEN 75/M-IND/PER/7/2010 bahwa 70 karyawan membutuhkan 5 tempat pencuci tangan. Jumlah toilet yang tersedia adalah 8 toilet untuk 67 karyawan. Jumlah fasilitas toilet ini sudah sesuai dengan PERMEN 75/M-IND/PER/7/2010 untuk 70 karyawan membutuhkan 4 toilet yang seharusnya tersedia di dalam UPI. Toilet dan tempat cuci tangan dilengkapi sabun dan hand dryer untuk membantu sanitasi dan hygiene karyawan berjalan dengan baik sehingga tidak terjadi kontaminasi yang dapat menimbulkan kemunduran mutu produk yang diolah. Menurut Murniati dan Sunarman (2000), salah satu usaha yang dapat 
dilakukan untuk mempertahankan mutu ikan terhadap pembusukan adalah melindungi ikan terhadap kontaminasi bakteri dan penyebab kerusakan lain yang datang dari luar.

\section{Perlindungan terhadap Bahan-bahan Kontaminan}

Tindakan monitoring yang dilakukan PT Permata Marindo Jaya adalah :

1. Bahan-bahan yang berpotensi toksin dicek setiap hari sekali oleh QC.

2. Penyimpanan bahan pengemas dicek setiap hari oleh QC.

3. Aliran udara dan potensi kondensasi dicek setiap 4 jam oleh QC.

\section{Syarat Label dan Penyimpanan Bahan Kimia}

Penerapkan prosedur pelabelan dan penyimpanan dengan baik, setiap bahan kimia diberi label yang jelas sehingga dapat dipahami dan penyimpanan bahan kimia induk terdapat di ruang bahan kimia yang terpisah dengan ruangan produksi, namun setiap bahan kimia seperti alkohol, klorin dan sabun pembersih di simpan di setiap sudut ruangan proses diberi label yang berbeda antar ruang proses, pemberian label ini bertujuan untuk membedakan penggunaan bahan kimia setiap ruangan dan menjaga agar tidak terjadi tercampurnya bahan kimia satu dengan yang lainya hal ini sudah sesuai dengan Thaheer, 2005 bahwa SSOP ini mencakup tata cara dan jenis pelabelan yang diterapkan pada bahan-bahan kimia yang digunakan, baik untuk produksi maupun pembersihan fumigasi, desinfeksi, dan sebagainya.

\section{Kesehatan Karyawan}

Karyawan harus dalam kondisi sehat dan tidak menderita penyakit infeksi selama bekerja di area produksi. Petugas keamanan proses harus memeriksa kondisi karyawan sebelum mereka memasuki area proses. Monitoring yang dilakukan PT Permata Marindo Jaya adalah:

1. Pengecekan surat kesehatan personil saat penerimaan oleh personalia

2. Evaluasi hasil pelatihan karyawan oleh QC.

3. Pengecekan tanda-tanda penyakit (diare, demam, muntah, penyakit kuning, radang tenggorokan dan lainnya)

4. QC memastikan semua karyawan mengikuti medical check-up.

\section{Pengendalian Hewan Pengerat (Pest)}

Pengendalian hewan pengerat (pest) yang dilakukan oleh PT. Permata Marindo Jaya adalah dengan memasang insect killer dan tirai plastik agar serangga dan hewan pengerat tidak dapat memasuki ruang produksi.

Monitoring dilakukan oleh PT. Permata Marindo Jaya adalah :

1. Pengecekan visual, gunakan cahaya (flashlight) untuk mengetahui tempat tersembunyi dan perangkap binatang. Menjaga kebersihan dan memfasilitasi pengawasan setiap hari oleh QC.

2. Cek akses masuk pintu, jendela, ventilasi, saluran air pembuangan setiap hari oleh QC.

3. Cek lampu setiap hari oleh QC.

Tindakan koreksi yang dilakukan adalah tambahkan air curtain di atas pintu luar dan pindahkan wadah buangan keluar. 
Buletin JSJ, 1 (1), 2019, 1-13

Available online di: http://ejournal-balitbang.kkp.go.id/index.php/JSJ/index

\section{Pemantauan Titik-Titik Kritis}

Prosedur pemantauan titik-titik kritis / Critical Control Points (CCP) yang dilakukan adalah

1. Bahaya Signifikan : Histamin (Tahapan Penerimaan Bahan Baku)

Prosedur pemantauannya adalah pengecekan Approval Supplier, Uji histamin laboratorium internal minimal $18 \mathrm{ikan/lot} \mathrm{(komposit} \mathrm{3)} \mathrm{setiap} \mathrm{penerimaan.}$

2. Bahaya Signifikan : Clostridium botulinum (Tahapan Pelelehan)

Prosedur Pemantauannya adalah kontrol suhu produk $<3,3^{\circ} \mathrm{C}$ setiap 2 jam sekali oleh QC.

3. Bahaya Signifikan : Histamin (Tahapan Penyimpanan Sementara)

Prosedur pemantauannya adalah Kontrol suhu produk tidak boleh $>3^{\circ} \mathrm{C}$ setiap 2 jam oleh QC.

4. Bahaya Signifikan : Clostridium botulinum (Tahapan Pendinginan Sementara)

Prosedur pemantauannya adalah Kontrol suhu Chilling room dengan data logger tidak boleh $>3^{0} \mathrm{C}$ setiap 2 jam sekali.

5. Bahaya Signifikan : Histamin (Tahapan Penyimpanan Sementara)

Prosedur pemantauannya adalah Kontrol suhu Chilling room dengan data logger tidak boleh $>3^{\circ} \mathrm{C}$ setiap 2 jam sekali.

6. Bahaya Signifikan : Serpihan Logam (Tahapan Pendeteksian Logam)

Prosedur pemantauannya dalah Masukkan setiap produk ke alat metal detector dan cek sensitivitas mesin sebelum, 2 jam sekali dan setelah proses.

7. Bahaya Signifikan : Clostridium botulinum (Tahapan Pengemasan dan Pelabelan)

Prosedur pemantauannya adalah QC mengecek label tertera keep frozen, thawing under refrigeration, produk yang sudah dilelehkan tidak dapat dibekukan ulang sebelum proses pengepakan dan pelabelan.

8. Bahaya Signifikan : Allergen

Prosedur pemantauannya adalah QC melakukan cek label apakah tertera allergen (tuna) sebelum proses pengepakan dan pelabelan.

\section{Penetapan dan Pengendalian Titik kendali kritis}

Histamin adalah bahaya yang merupakan salah satu titik kendali kritis di PT Permata Marindo Jaya. Berdasarkan Tabel 2, bahwa bahaya histamin pada tahapan proses penerimaan bahan baku merupakan bahaya yang memiliki tindakan pengendalian yang bersifat mencegah bahaya tersebut yaitu persyaratan surat jaminan supplier dan pengujian histamin pada bahan baku. Tahapan proses tersebut tidak dirancang khusus untuk menghilangkan atau mengurangi bahaya sampai tingkatan yang diterima, tetapi histamin ini sangat mudah untuk meningkat dan terjadi melebihi tingkatan yang diterima apabila suhu lebih dari $4,4^{\circ} \mathrm{C}$. Tahapan berikutnya tidak dapat mengurangi histamin meskipun proses pembekuan atau proses penyimpanan beku sehingga bahaya ini menjadi titik kritis atau critical control point. Prosedur pemantauan yang dilakukan perusahaan untuk bahaya histamin adalah Surat Garansi Supplier (Approval Supplier), Uji histamin pada laboratorium internal minimal 18 ikan/lot (komposit 3) setiap penerimaan dan audit supplier setiap 1 tahun sekali. Menurut FDA (2011) prosedur pengendalian untuk bahaya histamin meliputi pengendalian kapal saat bongkaran, pengujian histamin, pemantauan pembongkaran di tempat transit, pemantauan saat proses dan pemantauan penyimpanan. 
Tabel 2. Penetapan Titik Kendali Kritis Histamin

\begin{tabular}{|l|c|}
\hline \multicolumn{1}{|c|}{ Tahapan Proses } & $\begin{array}{c}\text { Penerimaan Bahan } \\
\text { Baku }\end{array}$ \\
\hline Bahaya & Histamin \\
\hline $\begin{array}{l}\text { Apakah ada tindakan pencegahan pada tahapan tersebut untuk } \\
\text { mencegah atau meminimalkan bahaya yang mungkin terjadi }\end{array}$ & YA \\
\hline $\begin{array}{l}\text { Apakah tahap ini didesain khusus untuk dapat menghilangkan } \\
\text { atau mengurangi kemungkinan terjadinya hazard sampai tingkat } \\
\text { yang diterima. }\end{array}$ & Tidak \\
\hline $\begin{array}{l}\text { Apakah bahaya yang terjadi dapat meningkat melebihi level yang } \\
\text { dapat diterima atau melebihi batas kritis. }\end{array}$ & YA \\
\hline $\begin{array}{l}\text { Apakah tahapan berikutnya dapat mengurangi bahaya signifikan } \\
\text { yang telah diidentifikasi pada tahapan tersebut }\end{array}$ & Tidak \\
\hline Hasil & CCP \\
\hline
\end{tabular}

\section{KESIMPULAN}

1. Pengamatan Good Manufacturing Practises (GMP) proses pengolahan tuna steak beku dilaksanakan dengan baik, namun penerapan prosedur GMP penerimaan bahan baku yaitu audit approval supplier kurang dilakukan dengan ketat dibuktikan dengan sanitasi, penanganan yang baik dan higienis kurang dilakukan saat pembongkaran ikan.

2. PT Permata Marindo Jaya telah menerapkan 8 kunci sanitasi sesuai prosedur perusahaan namun pencegahan kontaminasi silang belum sepenuhnya diterapkan karena masih ditemukan klip hitam besi di ruang UV 1 yang dapat mencemari produk dengan serpihan logam.

3. Pengendalian titik kendali kritis histamin sudah dilakukan dengan baik yang dibuktikan dengan hasil uji histamin dari 7 kapal pada penerimaan bahan baku, saat proses (setelah $\mathrm{CO}$ ) dan produk akhir tidak ada yang melebihi standar perusahaan yaitu $17 \mathrm{ppm}$.

\section{DAFTAR PUSTAKA}

Afrianto, E dan E Liviawaty. (1989). Pengawetan dan Pengolahan Ikan. Yogyakarta : Konisius.

Badan Standarisasi Nasional. (2016). SNI 2354.10:2016. Cara uji kimia- bagian 10: Penentuan kadar Histamin dengan Spektrofotometri dan Kromatografi Cair kinerja tinggi (KCKT pada Produk Perikanan. Jakarta : Dewan Standarisasi Nasional.

Badan Standarisasi Nasional. (2006). Standar Nasional Indonesia (SNI 01-4485.1-2006). Tuna steak beku - Bagian 1: Spesifikasi. Jakarta : Dewan Standarisasi Nasional.

Badan Standarisasi Nasional. (2006). Standar Nasional Indonesia (SNI 01-4485.2-2006) . Tuna steak beku - Bagian 2: Bahan Baku. Jakarta : Dewan Standarisasi Nasional Indonesia

Badan Standarisasi Nasional. (2006). Standar Nasional Indonesia (SNI 01-4485.3-2006). Tuna steak beku - Bagian 3: Penanganan dan Pengolahan. Jakarta : Dewan Standarisasi Nasional.

Commission, E. (2001). Opinion of the Scientific Committee on Food on the use of carbon monoxide as component of packaging gases in modified atmosphere packaging for fresh meat. Uni Eropa. 
Buletin JSJ, 1 (1), 2019, 1-13

Available online di: http://ejournal-balitbang.kkp.go.id/index.php/JSJ/index

Departemen Kelautan dan Perikanan. (2007). Keputusan Menteri Kelautan dan Perikanan nomor: KEP.011/MEN/2007, Tentang Persyaratan Jaminan Mutu dan Keamanan Hasil Perikanan pada Proses Produksi, Pengolahan, dan Distribusi. Jakarta : Dinas Kelautan dan Perikanan

Djenane, D. (2018). Carbon Monoxide in Meat and Fish Packaging : 1-34. Diakses pada 03 maret 2019 dari https://doi.org/10.3390/foods7020012

Food and Drug Administrations. (2007). Federal Regulation of Substances Generally Recognized As Safe ( GRAS ) and the Use of Carbon Monoxide in Packaging for Meat and Fish American Law Division. Florida: Departement of Health and Human Services Public Health Service Food An Drug Administration Center for Food Safety and Applied Nutrition Office of Food Safety.

Food and Drug Administrations. (2011). Fish and Fishery Products Hazards and Controls Guidance (Fourth Edi). Florida: Departement of Health and Human Services Public Health Service Food An Drug Administration Center for Food Safety and Applied Nutrition Office of Food Safety.

Junianto. (2003). Teknik Penanganan Ikan. Jakarta : Penebar Swadaya.

Keputusan Kementerian Kelautan Dan Perikanan. 2013. KEPMEN Nomor 52a/KEPMENKP/2013 Tentang Persyaratan Jaminan Mutu Dan Keamanan Hasil Perikanan Pada Proses Produksi, Pengolahan dan Distribusi. Jakarta : Kementerian Kelautan Dan Perikanan

Koutchma, T. (2014). UV Light for Processing Foods. Agriculture and Agri-food. Canada. Diakses pada 05 maret 2019 dari https://doi.org/10.1080/01919510701816346

Nurjanah, Asadatun Abdullah, Kustiariyah. (2011). Pengetahuan dan Karakteristik Bahan Baku Hasil Perairan. Bogor : IPB Press.

[PERMEN] Peraturan Menteri Kelautan dan Perikanan. (2007). Permen Nomor PER. 01/MEN/2007 tentang Pengendalian Sistem Jaminan Mutu dan Keamanan Hasil Perikanan. Jakarta : Peraturan Menteri Kelautan dan Perikanan.

Peraturan Menteri Kesehatan. 2010. PERMENKES No 49/MENKES/PER/V/2010. Persyaratan Kualitas Air Minum. Jakarta : Menteri Kesehatan.

Peraturan Menteri Perindustrian. 2010. Permen Nomor 75/M-IND/PER/7/2010 tentang Pedoman Cara Produksi Olahan yang Baik. Jakarta : Peraturan Menteri Perindustrian.

Rosal, A. R. R., \& Agüera, J. A. P. M. M. A. (2008). Ozone-Based Technologies in Water and Wastewater Treatment. 5(February), 127-175.

Sahril, D. F., \& Lekahena, V. N. J. (2015). Pengaruh Konsentrasi Asam Asetat terhadap Karakteristik Fisikokimia Tepung Ikan dari Daging Merah Ikan Tuna. Jurnal IImiah Agribisnis Dan Perikanan (Agrikan UMMU-Ternate), 8 edisi 1.

Stermer, R. A., Lasater-smith, M., \& Brasington, C. F. (1987). Ultraviolet Radiation - An Effective Bactericide for Fresh Meat. 50(2), 108-111.

Suwetja., I.K. 2011. Biokimia Hasil Perikanan. Jakarta : Media Prima Aksara.

Thaheer, Hermawan. 2005. Sistem Manajemen HACCP. Jakarta : Bumi Aksara.

Vermeulen, N., Keeler, W. J., Nandakumar, K., \& Leung, K. T. (2008). The Bactericidal Effect of Ultraviolet and Visible Light on Escherichia coli. Diakses pada 0 mei 2019 pada https://doi.org/10.1002/bit.21611 